\title{
木造伝統構法五重塔の設計にお STRUCTURAL DESIGN OF ける構造安全性の検討 TRADITIONAL WOODEN FIVE- STORIED PAGODA
}

$\begin{array}{ll}\text { 花里利一—*1 } & \text { 荻原幸夫 —*2 } \\ \text { 稲山正弘—*3 } & \text { 大倉靖彦—*4 } \\ \text { 三井所清典—*5 } & \text { 坂本 功—*6 }\end{array}$

キーワード

木構造，五重塔，構造設計，構造解析，補強

Keywords :

Timber structure, Five storied pagoda, Structural design, Structural analysis, Strengthening

\author{
Toshikazu HANAZATO $-* 1$ \\ Masahiro INAYAMA — - $* 3$
}

Kiyonori MIISHO

Yukio OGIWARA - *2
Yasuhiko OKURA $-* 4$
Isao SAKAMOTO - *6

A traditional wooden five-storied pagoda was structurally designed on the basis of the performance design concept against wind, earthquake and snow loads. The present paper describes the design loads evaluation, the non-linear structural analyses, and the strengthening techniques. The static wind and the earthquake response analyses were successfully performed in consideration of the key mechanisms such as the semi-rigidity at the column-beam joints. The calculated story drifts showed that the strengthened structure would be safe against the design loads for the return period of 200 years.
1.はじめに

本設計研究は、木造五重塔を設計する立場から、現代の構造解析 技術を適用して、伝統構法による新設五重塔の構造安全性の検討を 実施したものである。設計建物を工作物とみなして、200 年再現期 待値の地震・風荷重に対して倒壊しないとする目標性能を設定し、 構造解析により目標性能を满たすことを確認した。目標性能を表す 安全指標は層間变位角とし、実験研究の文献 ${ }^{1)}$ に基づいて、設計荷 重に対して $1 / 30$ 以内に収まることとした。

歴史的に、木造五重塔が地震で倒壊した記録はないとされている が、室戸台風(1934)における大阪の四天王寺五重塔のように台風に よる倒壊の記録は少なくない。本検討は、木造五重塔の耐震・耐風 性能について、現代の構造力学に基づいて定量的な解釈を試みたも のとしても位置付けられる。 を基に、構造安全性と構造補強法の検討を行った。まず、宮大工に よる木造架構の設計図書に基づいて、水平耐力を概算した結果、概 算荷重に対して耐力が足りないことがわかり、各重における貫の追 加と板壁の設置、初重足元貫の補強を施す設計修正を行った。さら に、柱引き拔き荷重や屋根吹き上げ荷重に対して補強金物を設けた。 本構造検討では、耐風解析は主として静的增分解析、耐震検討は主 として地震応答解析によるものとした。設計荷重は、基本的に建築 学会『建築物荷重指針』の考え方に基づいて評価した。

木材の材料強度・剛性に注、建築学会『木質構造設計規準』に示 されている上級構造材(ひのき・ひば)の值を用いた。
意匠・構法も含めた基本的な設計は宮大工が行い、その設計図書

\section{2. 建物の概要}

本建物は北陸地方の港湾に面した宅地内に計画されたものである。 立断面および三重桔木伏を図 1 ,図 2 に示す。江戸後期の構法を取り 入れた宮大工の設計では、(1)心柱の迴りに 4 本の四天柱と 12 本の側 柱を配し、桁(丸析桔木)上にほぞ接合により立てる。側柱上には斗 組を組立て、四天柱は上重の丸析桔木まで延ばす。(2)側柱通と四天 柱通において柱間に貫を通す。初重床下には足元貫を通す。(3)斗組 は耐力を確保するため斗-时木の一体化を計る。(4)初重のみ裳階を設 け、相輪頂高さは $21.8 \mathrm{~m}$ 、五重屋根上の路盤高さは $15.8 \mathrm{~m}$ 。初重平 面は側柱間 $3.4 \mathrm{~m}$,裳階柱間 $5.4 \mathrm{~m}$ 。(5)柱は丸标桔木にほぞにより接合。 木材の収縮対策として、各重の四天柱下と心柱下に隙閒を設ける。 (6)心柱は、四重と五重の桔木で支えて吊り下げる。(7)使用樹種は国 産のひのき、ひば。屋根は銅板平蕞き。

\section{3. 設計荷重の評価}

\section{1 鉛直荷重}

固定荷重の算定では、建築学会規準を参照し、使用樹種(ひのき・ ひば)の設計比重を 0.50 (含水率 $30 \%$ )として、部材重量を設計図書か ら算出した。その結果、木造五重塔の総重量は $48.3 \mathrm{tf}$ と求まった。

本設計建物は多雪地域にあり、積雪荷重を長期荷重に対する構造 検討および地震荷重との組合わせによる耐震検討に用いる。長期応 力検討に用いること、地震との組み合わせを考慮すれば、建築学会 荷重指針に比べて基準法施行令の方が大きな荷重となることをふま え、施行令の規定に基づき、県が定める最樑積雪量 $(150 \mathrm{~cm})$ と単位 重量 $\left(3 \mathrm{kgf} / \mathrm{cm} / \mathrm{m}^{2}\right)$ を採用した。高さ方向の各重屋根の積雪分布は、

\footnotetext{
${ }^{* 1}$ Tajimi Engineering Services, Ltd., Dr. Eng.

*2 Tajimi Engineering Services, Ltd.

*3 Inayama Architect, Dr. Eng.

*4 Director, ALSED

*5 Prof., Shibaura Institute of Technology/Director, ALSED

*6 Prof., University of Tokyo, Graduate School of Engineering, Dr. Eng.
}

(テ160-0023 新宿区西新宿3-2-26)

*2 (株田治見エンジニアリングサービス

*3 株稲山建築設計事務所 L博

*4 (侏アルセッド建築研究所 副所長

*5 芝浦工業大学亡学部建築学科 教授/アルセッド建築研究所代表

*6 東京大学大学院 L学系研究科 教授・工博 


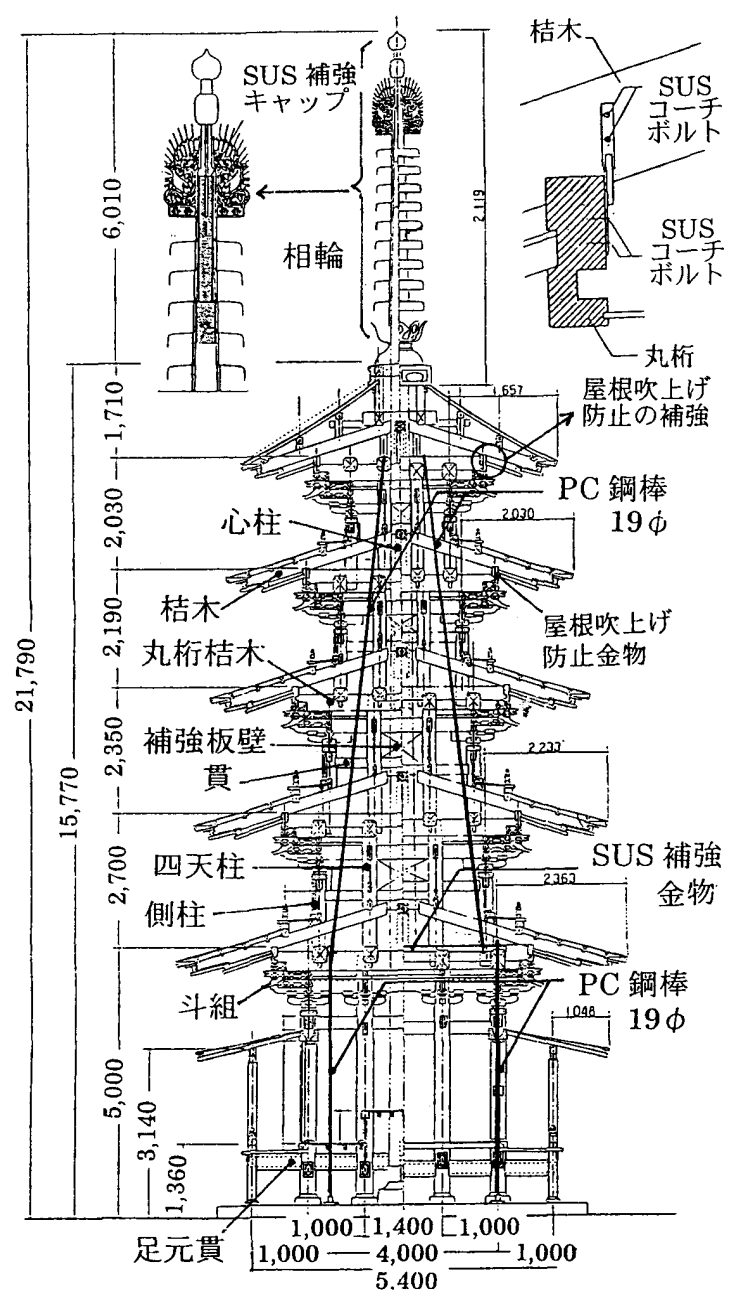

図 1 立断面(宮大工による設計図に補強を追記)

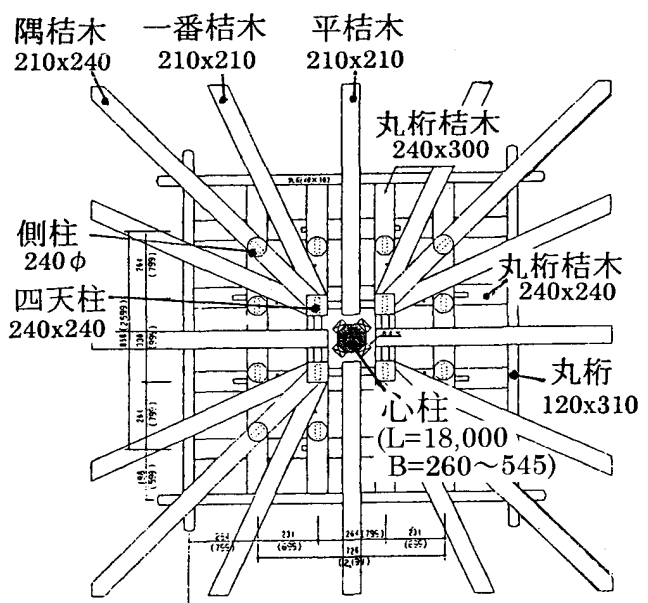

図 2 三重の桔木伏図(宮大工による設計図)

各重屋根の鈶直上方からの見付け面に積もると仮定し、初重から四 重までは軒下への吹込みを考慮して割増係数 2.0 を乗じた。長期応 力検討、耐震検討に用いる屋根上積雪荷重は、それぞれ合計 $32.4 \mathrm{tf}$ 、 $16.2 \mathrm{tf}($ 施行令に示されている数值 0.35 より)と算定した。

\section{2 水平荷重}

地震荷重の評価では、荷重の信頼性を高めるために 1600 年〜 1995 年の歴史地震データベースを用いた地震ハザード解析を行った。ハ ザード解析では、距離減衰式に金井式(対数標準偏差 0.7)を用い、マ グニチュードの発生頻度モデルは G-R 式とした。計算の結果、基盤 における最大速度の 200 年再現期待值は 8.3kine と求まり、地盤增

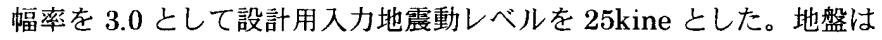
砂岩層 $(\mathrm{Vs}=$ 約 $500 \mathrm{~m} / \mathrm{s}$ )上に沖積砂質土層(厚さ約 $8 \mathrm{~m}, \mathrm{~N}$ 值 $=10 \sim 15$, $\mathrm{Vs}=140 \sim 160 \mathrm{~m} / \mathrm{s}$ )が堆積している。地盤での增幅については、地盤 特性のひずみ依存性を考慮した 1 次元せん断波動論による地震動解 析を実施し、最大速度の増幅率は約 $1.0 \sim 1.5$ であり、設定した地盤 増幅率 3.0 は十分に安全側であること、伝達関数(地表/砂岩層 GL$15 \mathrm{~m})$ のピーク振動数は約 $4 \mathrm{~Hz}$ と計算され、塔の固有周期(計算值 1.1 秒)に比べて十分に短いことを確認した。また、建築学会『基礎構造 設計指針』に基づいて、砂質土層の液状化判定を行い、設計入力地 震動レベルでは液状化は生じないと判定した。基礎工法は砂岩層に 支持した杭基礎とし、基礎マットスラブ(厚 $700 \mathrm{~mm}$ )と PHC 杭(埋込 み工法, 径 $400 \mathrm{~mm}$, 四隅側柱下に配置)の構造計算を行った。

風荷重については、建築学会『建築物荷重指針』を準用して、200 年再現期待値の設計荷重を算定した。構造骨組用水平風荷重の算定 における風力係数 $\left(\mathrm{C}_{\mathrm{f}}\right)$ やガスト影響係数 $\left(\mathrm{G}_{f}\right)$ の評価は、角柱の場合を 淮用し、 $\mathrm{C}_{\mathrm{f}}=1.4 、 \mathrm{G}_{\mathrm{f}}=2.0$ とした。基本風速 $\left(\mathrm{T}_{\mathrm{R}}=200\right.$ 年)は $30.0 \mathrm{~m} / \mathrm{s}$ である。見付け面積も安全側になるように、軒組み等を包絡するよ うな単純な形状に置換して求めた。その結果、初重層せん断力は $11.0 \mathrm{tf}\left(\right.$ ベースシェア倸数 $\left.\mathrm{C}_{\mathrm{B}}=0.23\right)$ と算定された。また、析に対して 斜め $45^{\circ}$ 方向風向の水平風荷重は見付け面積を $\sqrt{2}$ 倍して算定した。 㨝り風荷重や屋根吹上げ風荷重も同指針を準用して算定した。

3.長期の応力検討

鈶直荷重の流れを確かめるとともに、桔木と柱の断面応力と接合 部のめり込み応力が長期許容応力度以内におさまること、クリープ を考慮し、建築学会『木質構造設計規準』に従って岡性を $2 / 3$ に低 減しても桔木の変形は問題のない範囲におさまることを確認した。

\section{4.静的増分解析による耐震・耐風検討}

\section{1 解析モデル}

図 3 に示すように、木造五重塔の架構を四天柱通構面と側柱通構 面に分けて、平面並列骨組モデルで表した。各重桁レベルにおいて、 水平構面内の剛性が十分確保されていることを構造計算により確認 し(4.5 参照)、四天柱通之側柱通の水平変位は等しいと仮定した。ま た、心柱は四重と五重の桔木に支えられており、塔身に連結したモ デルとした。平面並列骨組モデルは、四天柱,側柱(柱頭は斗組)およ び心柱の鉛直材、貫,丸杵桔木の水平材および板壁で構成しており、

柱,貫,丸桁枯木は曲げせん断梁要素で表した。解析モデルの主な特徵 は、(1)柱-貫接合部の回転剛性を評価した半剛節ラーメン構造,(2)柱脚, 柱頭のピンもしくはピン・ローラーによる境界条件である。柱の傾 斜復元力は、設計上、安全側から考慮しておらず、傾斜復元力によ る酎力[ベースシェア概算值で 0.09 程度保有]は安全余裕として評価 した。本検討では、柱-貫接合部の回転剛性、板壁と斗組のせん断剛 性に非線形性を考虑した。

4.2 構造要素の力学モデル

\section{(1)柱-貫接合部}

図 4 に示すように、めり込み抵抗を考虑して、回転剛性と降伏モ 一メントで表せる弾塑性回転げねに置換した。通し貫と柱(内柱)の 接合部のめり込み評価式には稲山(1995)の提案式 1)を用いる。余長 が十分ではない外柱と貫の接合部は、図 5 に示すように中立軸を仮 


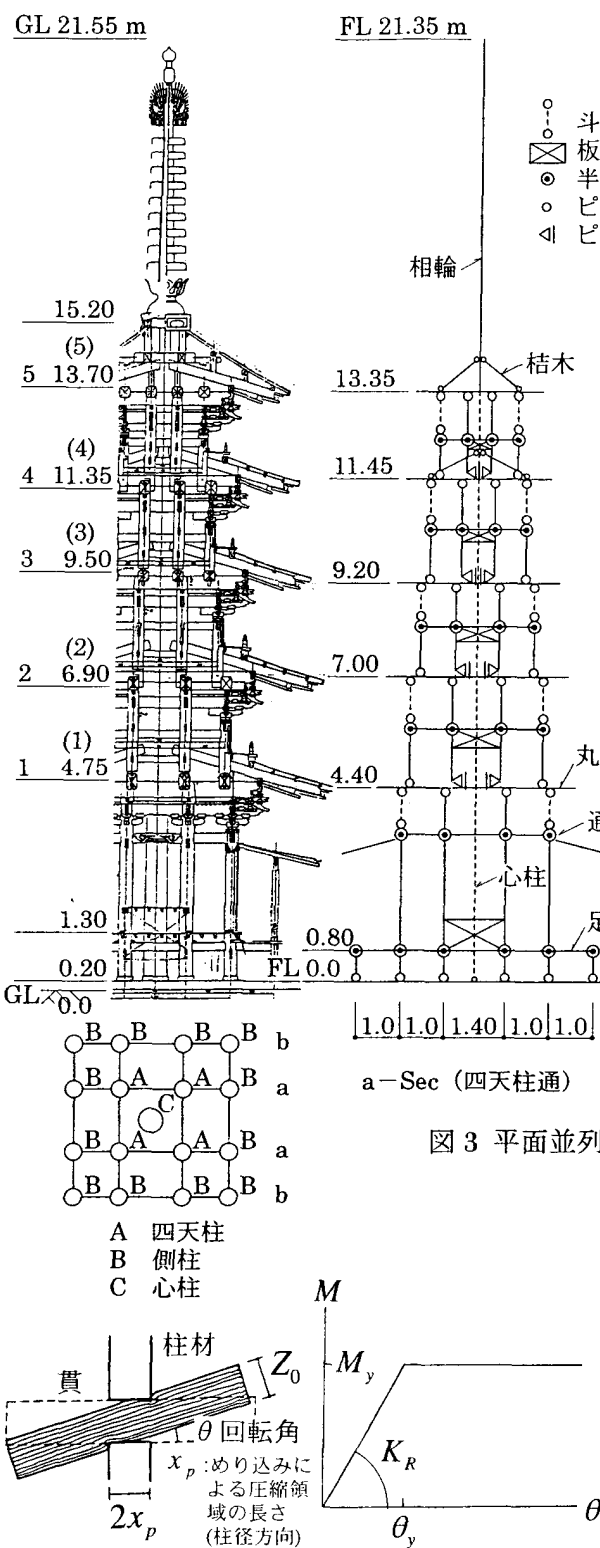

図 4 柱-貫接合部の力学モデル

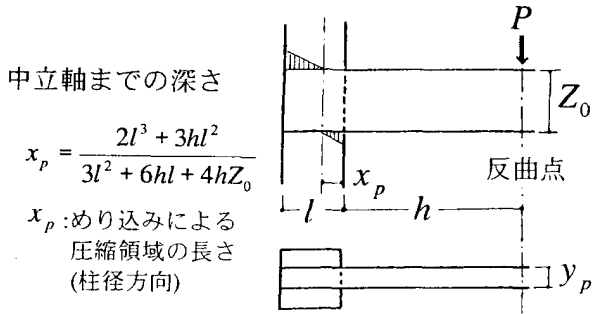

図 5 外柱と貫の接合部のモデル

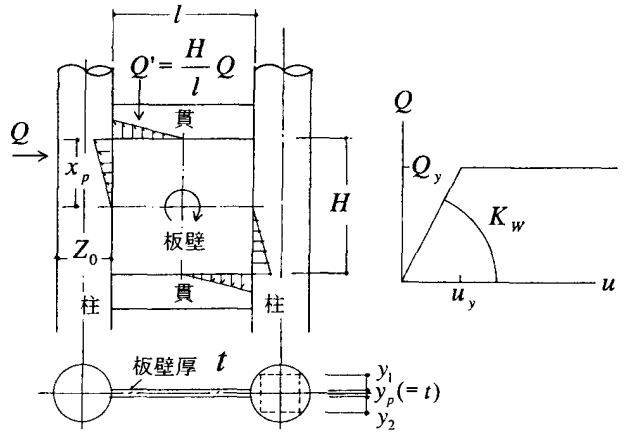

図 6 板壁の力学モデル
定して算定式を導いた(住1)。

(2)板壁

図 6 に示すように、四周枠材へのめり込みと板壁のせん断変形を 考慮して弾塑性せん断ばねに置換した。めり込み評価には 3 角形分 布の算定式 2)を用いた。

(3)斗組

せん断ばね剛性は木だぼによる接合部の剛性によって評価できる ものとし、だぼの主材に対するめり込み変位(図 7)とだぼのせん断変

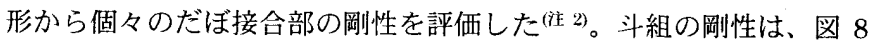
に示すように組合わせることにより算定した。

斗組の終局耐力もだぼの接合部で評価できるものとし、丸太組構法 の木だぼの終局耐力式 3)を用いて算定した。

斗組の圧縮剛性は、斗の台輪や肘木に対するめり込み剛性と、斗・ 大斗の圧縮剛性を組み合わせて算定した。めり込み剛性は等変位め り込み式 2によって与えた。一方、塔身に作用する引張荷重は、6.に 示すように、補強タイロッドが負担する。その引張剛性と斗組の圧 縮剛性がだいたい等しいことを確認し、本検討用モデルでは、圧縮 剛性の算定値を斗組の軸剛性(線形)とした。

4.3 固有周期の計算

解析モデルの妥当性の確認を主目的として、固有值解析を行った 結果、固有周期は 1.10 秒 (1 次)、0.78 秒(2 次)と算出された。伝統木 造多層塔の常時微動記録による固有周期(T)の実験式(山辺ら $(1988)^{4)}$ ) $\mathrm{T}=0.05 \mathrm{H}$ 秒 $(\mathrm{H}:$ 高 $[\mathrm{m}])$ を適用すると、本設計建物の場合、 $\mathrm{T}=0.76$ 秒 と計算される。しかし、常時微動による実験式は、ミクロンレベル
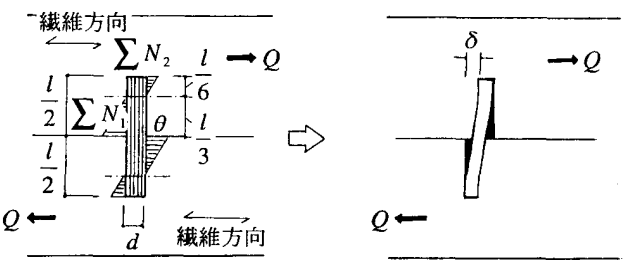

図 7 木だぼのめり込み算定モデル
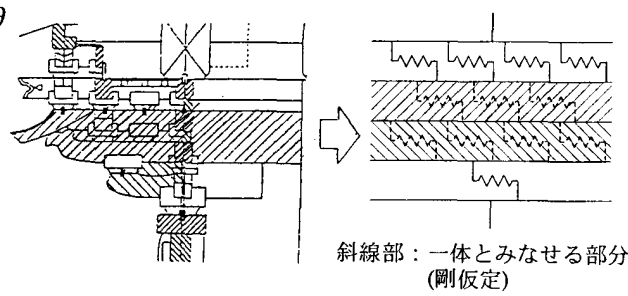

図 8 斗組のせん断剛性算定モデル

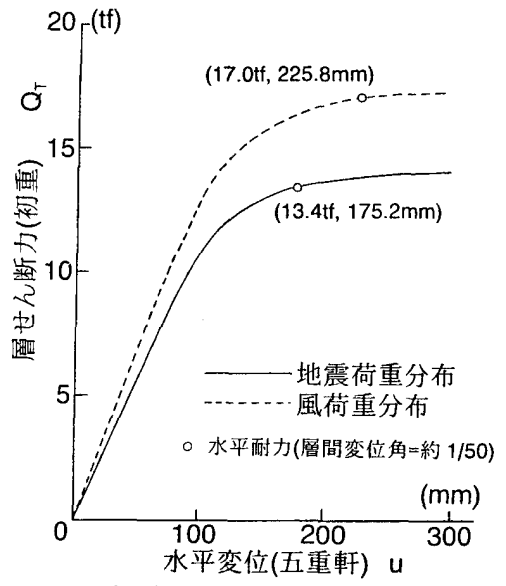

図 9 初重層せん断力と五重水平変位

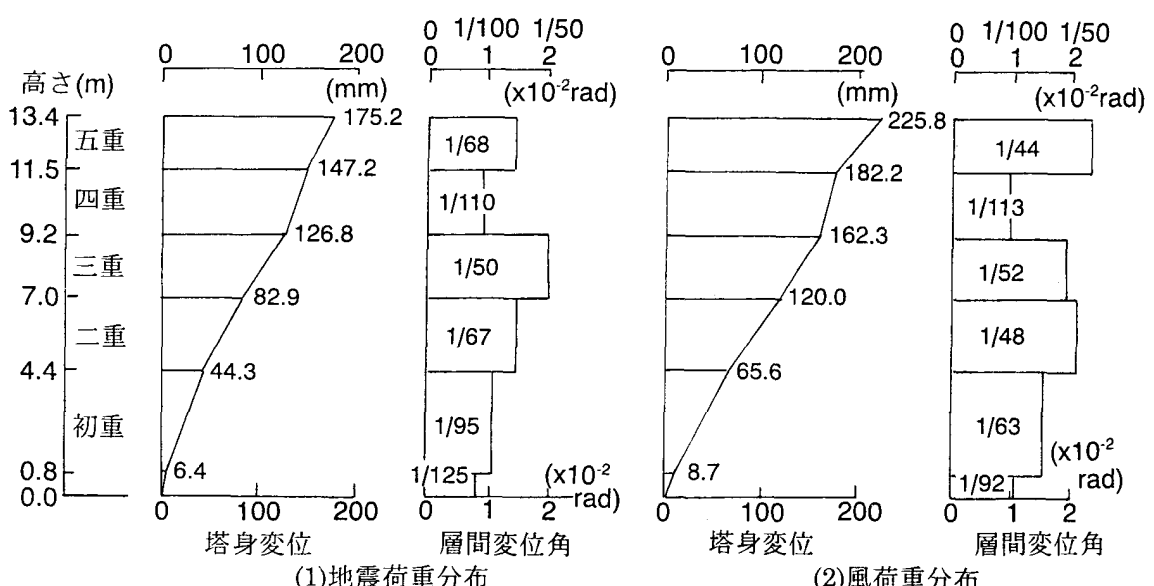

図 10 層間変位角に基づく水平耐力時における塔身変位・層間変位角 
の微小な変位レベルに対応するものである。本解析モデルでは、接 合部のめり込みによる回転角で $1 / 200(\mathrm{rad})$ 程度の割線剛性に相当す る剛性を用いており、固有周期の計算値はだいたい妥当な值である。 4.4 静的增分解析の結果

(1)変形比

塔身の水平変位(五重軒高さ)は線形範囲内において、貫接合部の めり込みに伴う回転による変位が約 $54 \%$ を占め、架構のせん断変形、 曲げ変形による成分はそれぞれ、約 $40 \%$,約 $6 \%$ と算定された。 (2)水平耐力

図 9 に静的增分解析による初重層せん断力と五重(軒高さ)の水平 変位を示す。本設計検討では、安全指標値を首間変位角 $1 / 30$ とした が、以下の理由により、最大首間変位角が約 $1 / 50$ に達したときの水 平荷重を設計水平耐力とみなす。i)層間変位角が約 1/50 を超えると、 荷重のごくわずかな増分で変位が急激に増大する。ii)風荷重の場合、 見付け面積の羑により析平行風向に比べて斜め方向風向による荷重 の方が大きいと推定される。本検討では、見付け面積が最大となる 斜め $45^{\circ}$ 方向を考え、見付け面積の比率から設計荷重を $\sqrt{2}$ 倍した。 ここで、 $45^{\circ}$ 方向の荷重と変位ベクトルを柯方向に分解し、 $45^{\circ}$ 方 向の層間変位角を $1 / 30$ 以下に収めるために、朾方向の変位角をその $1 / \sqrt{2}$ 倍、すなわち、約 $1 / 50$ 以下とする。この仮定に基づいて層間 変位角 $1 / 50$ に対応する水平耐力を算定すると、図 9 に示すように、 地震荷重分布の場合、初重層せん断力 $\mathrm{Q}_{\mathrm{B}}=13.4 \mathrm{tf}$ (ベースシェア係数 $\left.\mathrm{C}_{\mathrm{B}}=0.28\right)$ 、風荷重分布の場合、 $\mathrm{Q}_{\mathrm{B}}=17.0 \mathrm{tf}\left(\mathrm{C}_{\mathrm{B}}=0.35\right)$ と求まった。 この水平耐力時における塔身変位と層間変位角分布を図 10 に示す。 (3)耐風安全性

図 11 に 200 年再現期待值の検討用水平風荷重 $\left(\mathrm{C}_{\mathrm{B}}=0.23\right)$ とそれに 対する塔身の変位、層間変位角分布を示す。図に示すように、高さ 方向の分布もおおむね滑らかで、層間変位角は $1 / 190 \sim 1 / 130$ 程度と 算定され、安全指標を满足している。また、斜め $45^{\circ}$ 方向の風荷重 を考えて、層間変位角を $\sqrt{2}$ 倍しても安全指標値の範囲内に収まって いる。終局耐力に対する安全性を確認するために、(2)で算定した水 平耐力に対する設計荷重の安全率(荷重係数)をべースシェア比で表 すと、桁平行風向で 1.5 と算定された。なお、柱の引抜き荷重に対 しては、6.に示すように、補強用タイロッドを設けた。

4.5 水平面内剛性

丸桁桔木は上欠き式わたりあご掛け仕口で組まれており、図 12 に示すめり込み抵抗のモデルを仮定して、めり込み抵抗評価法 ${ }^{2)}$
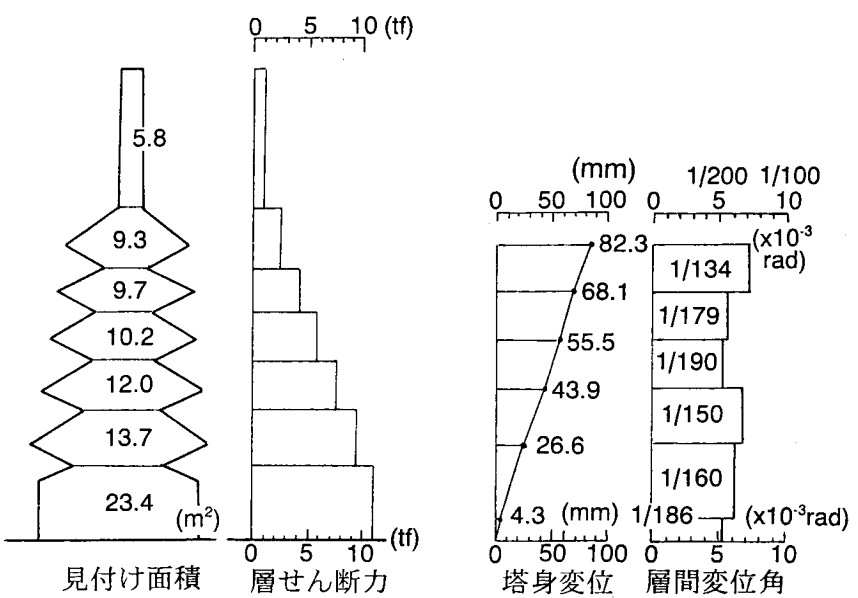

図 11 設計風荷重に対する塔身変位と層間変位角
基づいて、仕口の回転剛性 $\mathrm{K}_{\mathrm{R}}$ と降伏モーメント $\mathrm{M}_{\mathrm{y}}$ を算定した。さ らに、図13(初重の丸析桔木)に示すように、丸桁枯木を線形梁要素、 接合部を上記の非線形半剛節モデルで表した平面骨組モデルを設定 し、析に対して斜め $45^{\circ}$ 方向に設計風荷重が作用するとして、平面 架構の変形を計算した。風力倸数は設計值 $\mathrm{C}_{\mathrm{r}}=1.4$ とし、風上側、風 下側の風圧係数をそれぞれ、 $0.8 ，-0.6$ として、各節点に荷重を分配 した。解析の結果、丸桁桔木の変位、部材角は十分に小さく、水平 面内剛性は確保されており (図 14)、仕口に作用するモーメントも降 伏モーメントの算定值に比べて十分に小さいことを確認した。
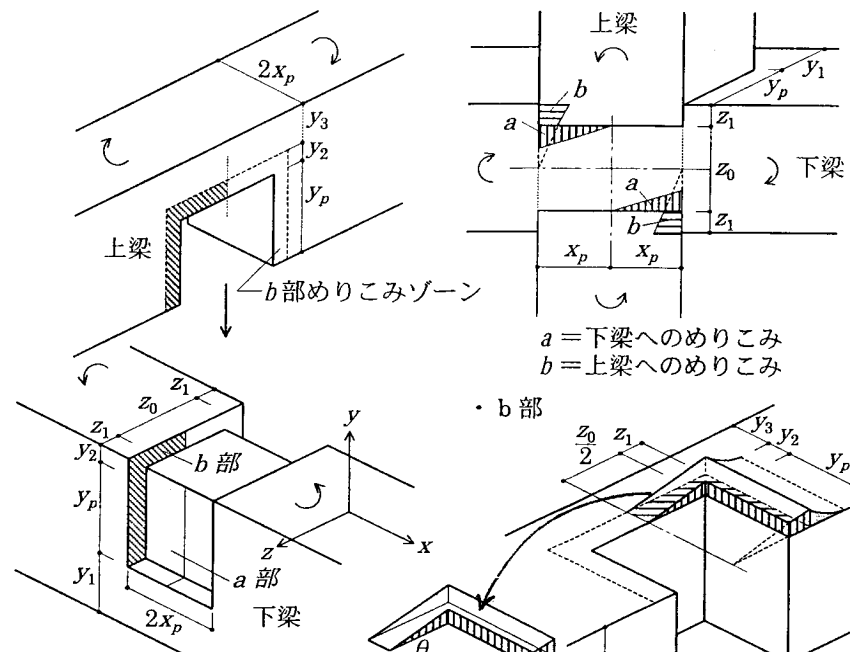

図 12 わたりあご掛け仕口のめり込み 抵抗算定气デル

丸桁桔木の断面寸法(初重)
上材 $=258 \times 324(\mathrm{~mm})$

上材 $=258 \times 324(\mathrm{~mm})$
下材 $=258 \times 379(\mathrm{~mm})$ " $\bigcirc$ 半剛接合節点

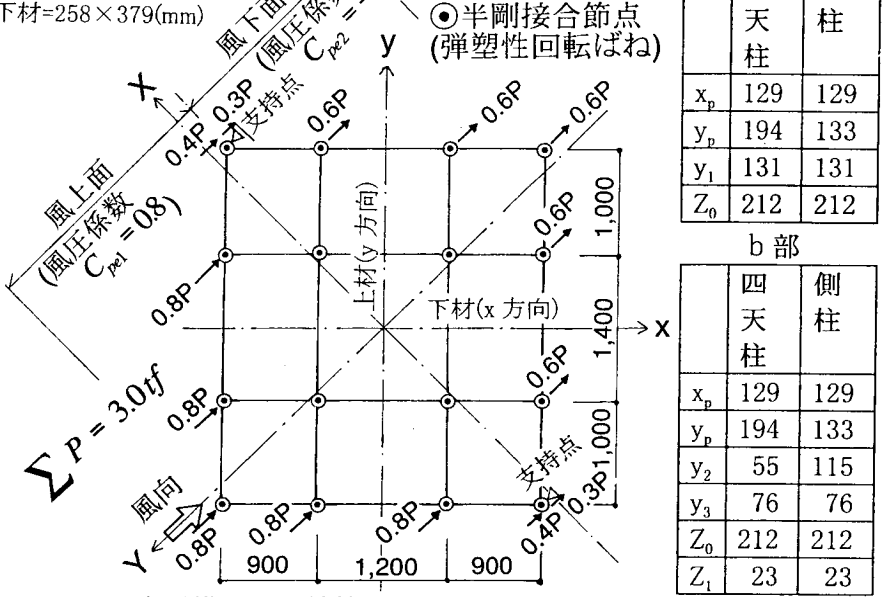

図 13 水平構面の剛性検討用の平面骨組モデル

(mm)

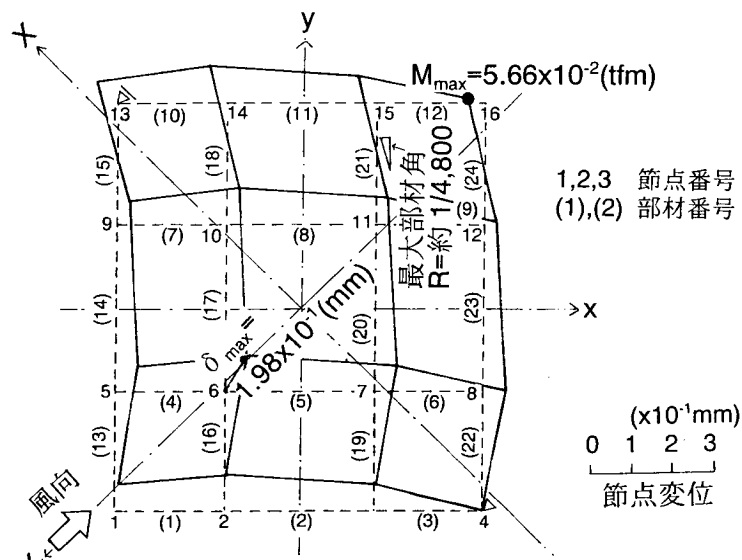

図 14 水平構面変位(初重の丸析桔木)の解析結果 
5. 地震応答解析

5.1 解析方法

平面並列骨組みモデルを曲げせん断型多質点系モデルに置換し(図 15)、ABAQUS を用いた非線形地震応答解析を行った。解析モデル は四天柱構面と側柱構面をひとつに集約し、層間のせん断変形は等 価な材端回転ばねを用いて表し、架構の曲げ变形を考慮して軸風性 を与えた。心柱は四重と五重で支持した曲げせん断梁要素とし、初 重から三重まで塔身との間には接触・非接触(問効果 ${ }^{5)}$ )を考慮するた めの要素(ギャップ要素)を取り付けた。宮大工の設計より、心柱と 塔身間の隙間は脚部(基壇)で $18 \mathrm{~mm}$ 、初重〜三重で $60 \mathrm{~mm}$ (桔木)と した。層間の荷重-変位関係は、静的增分解析結果に基づいて、エネ ルギー等価な完全弾塑性型(本稿ではバイリニア型と呼称)の復元力 特性を仮定した。減衰定数は剛性比例型(1 次固有振動に対して $5 \%$ ) とした。固有値解析の結果、 1 次固有周期は 1.11 秒(無積雪)、1.21 秒(積雪と組合わせ)と算定された。入力地震動は、設計用レベル (25kine)に基準化したエルセントロ 1940NS 波(最大加速度=255gal) タフト $1952 \mathrm{EW}$ 波(同 $248 \mathrm{gal}$ )、八戸 $1968 \mathrm{NS}$ 波(同 $165 \mathrm{gal}$ )とした。 5.2 解析結果

安全指標とした層間変位角の高さ方向分布(25kine 入力時)を図 16 に示す。積雪との組み合わせの有無によらず、約 1/50 以下に収まっ ており、安全指標を満たしている。なお、心柱と塔身の接触につい ては、脚部のみ接触し、初重〜三重では接触していない。

五重塔の耐震要素のひとつに、相輪の AMD 効果が挙げられる。 過去の地震でも相輪の損傷記録があることから、相輪が折れた場合 を想定した解析を行った。図 17 に塔身の層間変位角分布(タフト $\mathrm{EW}$ 波 25kine 入力)を示す。相輪の AMD 効果により二重〜三重の層間 変位が抑えられている。また、相輪がない場合でも層間変位角は最 大で約 $45 \%$ 程度(二重)大きくなるものの、安全指標の範囲内にほぼ 収まっている。さらに、安全余裕を確かめるため、入力レベル 50 kine(地震八ザード解析によれば再現期間約 800 年)とした解析を実 施したが、図 18(タフト $\mathrm{EW}$ 波入力)に示すように、塔身の層間変位 角は、安全指標の範囲内にだいたい収まっている。この入力レベル では、心柱と塔身は脚部だけでなく初重天井の桔木でも接触した。

本検討では、層間の荷重-変位関係にバイリニア型の復元力特性を 仮定した。一方、めり込みによる接合部の復元力特性は、実験結果 からスリップ型で表せる ${ }^{6)}$ 。復元力特性のモデル化の影響を把握す るために、検討用モデルを簡易モデルに置換して(図 19)、バイリニ ア型、スリップ型および履歴ループ面 積を低減した原点指向型の計 3 モデ ルを仮定した地震応答解析を行った。 バイリニア型の解析結果に対するスリ ップ型、原点指向型の層間変位角の比 率を図 20 に示す(エルセントロ NS,タ フト $\mathrm{EW}$ 波入力=25kine)。図 20 に示 すように、バイリニア型による結果に 対する比には入力地震動特性の影響が みられるが、図 16,17 に示した検討用 モデル(バイリニア型)の解析結果に、 この比率を考慮しても安全指標の範 网内にだいたい収まると推定される。

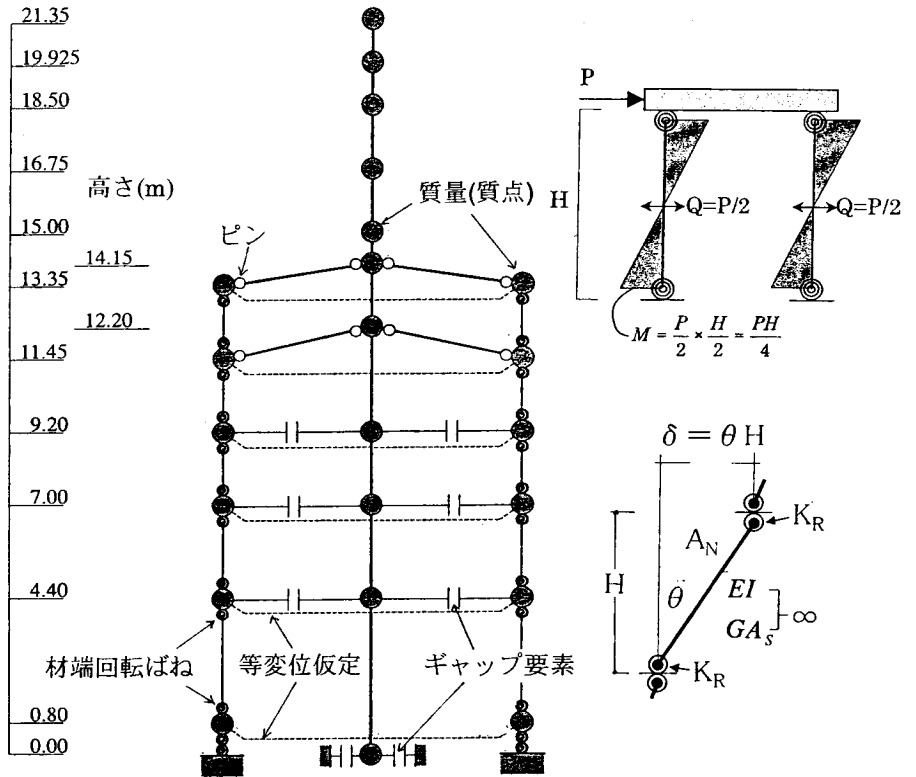

図 15 耐震検討用の動的解析モデル

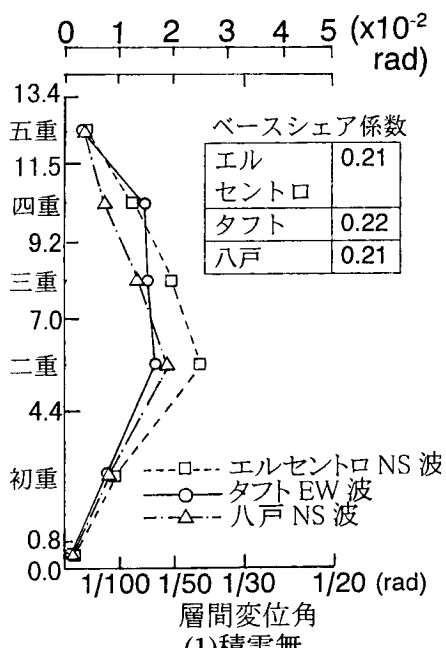

(1)積雪無

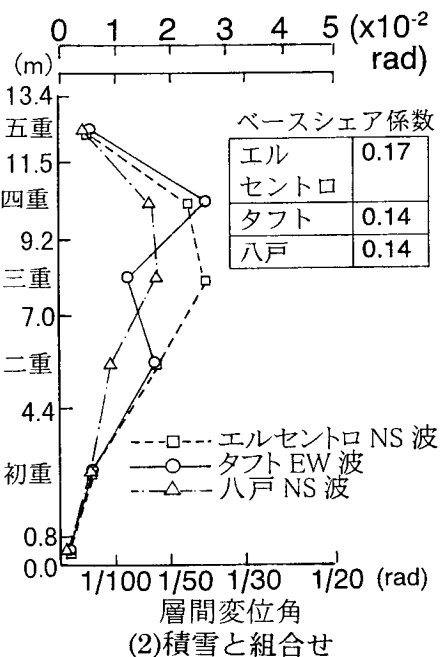

図 16 層間変位角(25kine 入力)
図 17 層間変位角(相輪の有無)

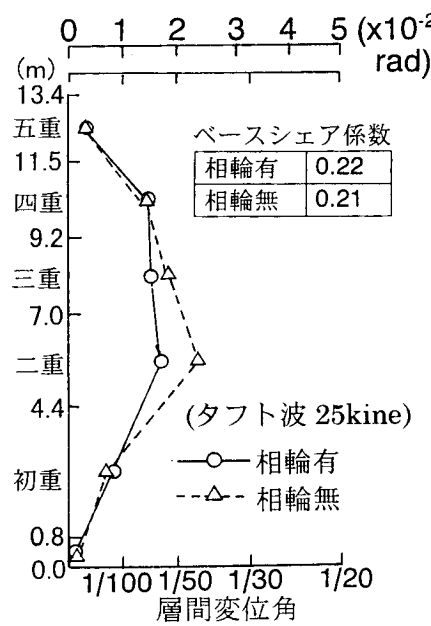

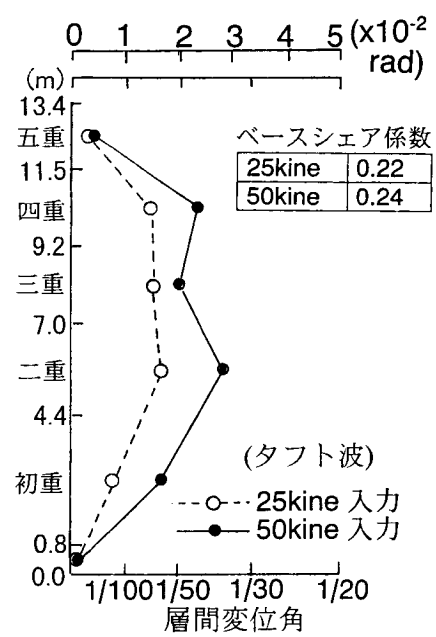

図 18 層間変位角 (25kine,50kine 入力)

\section{6. 補強金物の設計}

補強金物の設計では、暴風や地震による柱の引抜きに伴う倒壊を 防止するために基礎から五重天井の丸杵桔木までタイロッド(塗膜し た PC 鋼棒)を四隅に配している。初重には人が立ち入るため、意匠 的な配慮からタイロッドを壁中に通す工夫を施し、初重天井の丸桁 
桔木上にステンレス鋼材を設置して、上下のタイロッドを接続した。 タイロッドの設計荷重の算定では、柱の引抜き荷重が析に対して斜 め $45^{\circ}$ 方向風向の場合が最も大きくなることから、線形立体骨組解 析によりタイロッドの設計荷重を算定した。解析モデルは図 21 に示 すように、二重の貫より下部分をモデル化し、二重の貫より上にか かる荷重はモデル頭部の節点に作用させた。柱脚・柱頭は接合部の 力学条件をふまえてピンまたはピン・ローラーとし、柱-貫の接合部 は剛節とした。このモデルを用いて析平行風向および析 $45^{\circ}$ 方向風 向の設計用風荷重を外力として初重柱の軸力・せん断力分布を計算 した結果、タイロッド 1 本が負担する荷重は $19.0 \mathrm{tf}$ と求まった。設 計荷重は、屋根吹上げ風荷重分を加算して $23.9 \mathrm{tf}$ と算定し、 $\mathrm{P}$ C鋼 棒の径は JS 規格を参照して呼径 $19 \mathrm{~mm}$ (B 種)とした。また、屋根 に作用する吹上げ風荷重に対する対策としてステンレス製の補強金 物を設計した(図 1)。この設計荷重は、局部風圧(建築学会荷重指針 の外装材用風荷重)から求め、桔木を丸杵に固定する補強金物の設計 荷重は 1 個所あたり $830 \mathrm{kgf}$ とした。そのほか、相輪には心柱の延長 と相輪の落下防止を目的としてステンレス製キャップを取り付ける ことにした(図 1)。

\section{7. むすび}

目標性能を設定して、建設が計画されている木造伝統構法五重塔 の耐震・耐風・耐雪検討を行い、構造安全性を確認した。構造補強 の設計にあたっては、宮大工の伝統構法に対する考え方を尊重し、 伝統構法の歴史意医的な価値が損なわれないように工夫した。より 合理的な構造検討を行う上で、風荷重評価における風力係数、積雪 荷重評価における屋根上積雪分布、さらに、構造解析における斗組 · 板壁等の構造要素の力学モデルの検証が今後の課題である。

本検討は、著者のほか、宮澤正躬,佐藤貢一,池間典一(田治見エン ジニアリングサービス)、石塚正和,塙加寿雄(アルセッド建築研究所) による共同設計研究として実施した。詳細は文献 7)を参照されたい。

謝辞 一般設計は (有)白井大工 白井宏氏によるものです。本研究を 進めるにあたり、大成建設株式会社 柳澤孝次氏,森田仁彦氏にご協 カいただきました。また、田治見宏博士にご助言いただきました。

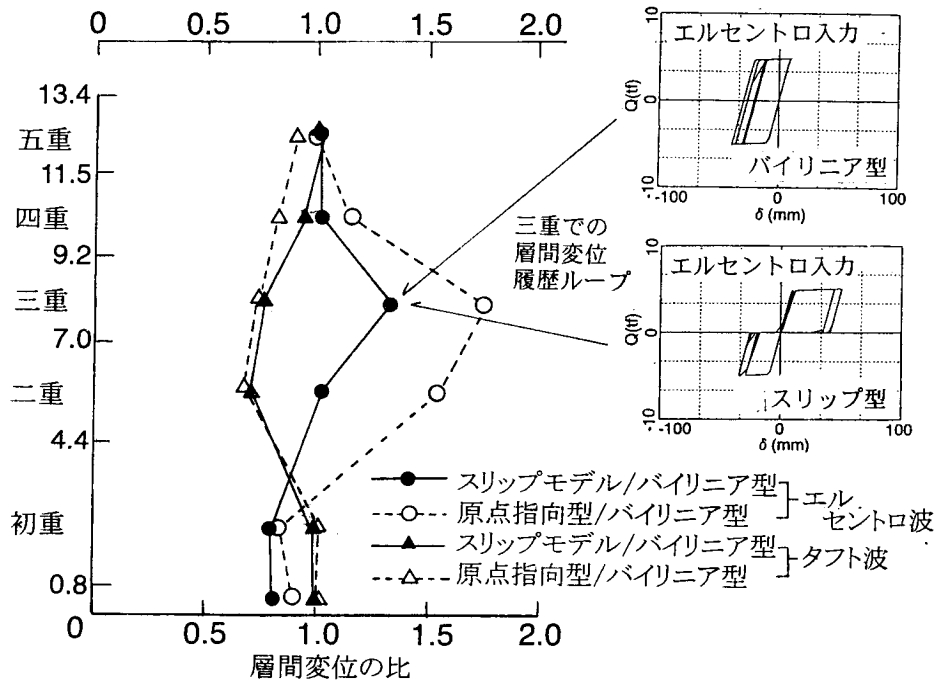

図 20 復元力特性のモデルによる層間変位角の比較 (バイリニア型を仮定した解析結果に対する比率)

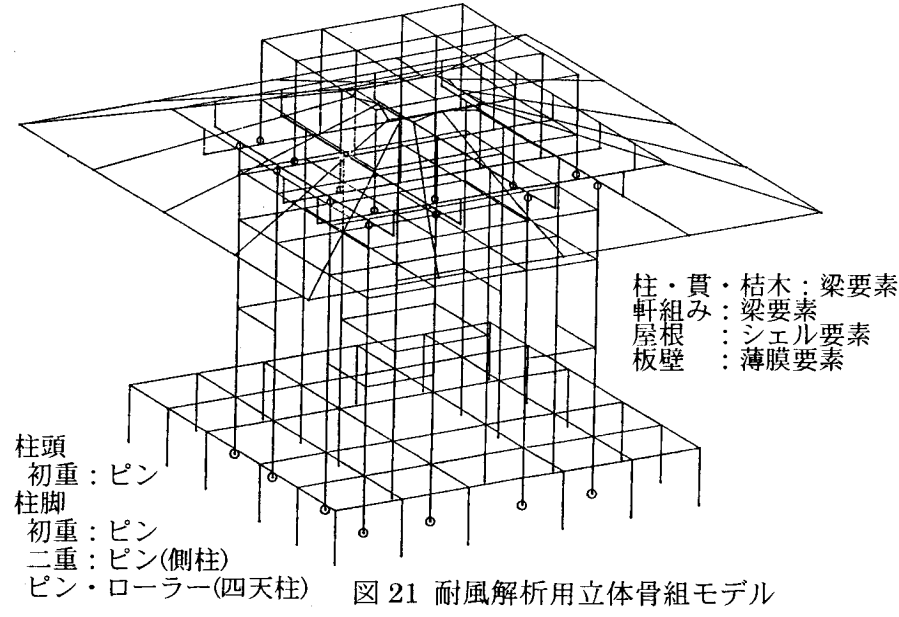

参考文献

1)菊池憲一,坂本功ほ力: 伝統的木造建築の構造診断(その 1 その 4) 建築学会大会梗概集,構造,pp 185-192,1996,同(その5〜その 6), 建築 学会大会梗概集,構造 III,pp215-218,1997

2)稲山正弘:めり込み抵抗接合の設計(貴構造),建築技術,pp 106-111, 1995

3)建築学会 : 木質構造設計ノート,1995

4)山辺克好,金井清 : 五重塔の耐震性に関する研究,日本大学生産工学 部報告,第 21 巻第 2 号,pp91-110,1988

5)石田修三:-心柱紀行-地震と五重塔,鉄鋼技術,1992 年 7 月 93 年 3 月号連載

6)稲山正弘:木材のめり込み理論亡その応用,東京大学学位論文,1991 7)三井所清典ほか:木造伝統構法五重塔の構造安全性の検討,(その1 その 6),建築学会大会梗概集,構造 IIII,pp277-288,1998

注

注 1 外柱-貫接合部の回転剛性の算定式(図 5)

回転剛性 $\left(K_{R}\right)$ は、中立軸までの深さを $x_{p}$ として、

$$
K_{R}=\frac{y_{p} E_{\perp}}{3 Z_{0}}\left\{2 x_{p}^{2} Z_{0}+x_{p}^{3}+\left(l-x_{p}\right)^{3}\right\}
$$

また、端距離効果倸数等の倸数は、

$C_{x}=1+\frac{2 Z_{0}}{3 x_{p}}\left\{2-e^{-\frac{3\left(l-x_{p}\right)}{2 Z_{0}}}\right\}, C_{x m}=1+\frac{4 Z_{0}}{3 x_{p}}, C_{y m}=1+\frac{4 Z_{0}}{3 n y_{p}}$

降伏変形角 $\left(\theta_{y}\right)$ と降伏モーメント $\left(M_{y}\right)$ は、

$$
\theta_{y}=\frac{Z_{0} f_{m}}{x_{p} E_{\perp} \sqrt{C_{x} C_{x m} C_{y m}}} \quad M_{y}=K_{R} \theta_{y}
$$

$\left(E_{\perp}\right.$ : 全面横圧縮ヤング係数 $E_{\perp}=\left(1 / n^{2}\right) E_{u}, n$ : 瀻維方向に対する直交方 向の置換係数 [本検討では $n=6], F_{m}$ : ゆり込み許容応力度 $=2.4 \times$ 辰期許 容めり込み応力度)

注2 木だぼのめり込み刷性の算定式 めり込み抵抗の評仙法を用いて算定式を尊いた。形状を角だぼとし、だ ぼのみがめり込むとするとすれば(図 7)、せん断力を $Q$,変位を $\delta$,めり込 み测性を $K_{w}$ として(ただし、ト式は $l \leq 3 d$ のときに付倅)、

$$
C_{y}=1, Z_{0}=d, y_{p}=d \text { より、 }
$$$$
\sum N_{1}=\frac{x_{p}^{2} y_{p} C_{y} E_{\perp} \theta}{Z_{0}}\left(\frac{1}{2}+\frac{2 Z_{0}}{3 x_{p}}\right)=\frac{l^{2}}{9}\left(\frac{1}{2}+\frac{2 d}{l}\right) E_{\perp} \theta
$$$$
\sum N_{2}=\frac{l^{2}}{36}\left(\frac{1}{2}-\frac{2 d}{l} d\right) E_{\perp} \theta \quad, Q=\sum N_{1}-\sum N_{2}
$$$$
\delta=\theta \times \frac{l}{3} \text { より、 } Q=\left(\frac{l}{8}+\frac{d}{3}\right) E_{\perp} \theta, \therefore K_{W}=\left(\frac{l}{8}+\frac{d}{3}\right) E_{\perp}
$$

[1998年 6 月24日原稿受理 1998 年11月 4 日採用決定］ 